\title{
Analysis of a diesel engine fuelled with jojoba blend and coir pith producer gas
}

\author{
S. K. Nayak* and P. C. Mishra \\ School of Mechanical Engineering, KIIT University, \\ Bhubaneswar-751024, Odisha, India \\ *E-mail: rohanrocks319@gmail.com, Mobile: +91-8763709850
}

\begin{abstract}
The emission characteristics of Jojoba biodiesel and preheated Jojoba oil blends along with producer gas from coir pith, in a dual fuel diesel engine under two different experimental conditions, were measured. The present experiment the emission characteristics of a diesel engine that was operated in dual fuel mode. The producer gas is the main fuel and jojoba biodiesel blends and jojoba preheated oil are the injected fuel. Firstly, diesel, biodiesel blends, and preheated oils with coir pith generated producer gas were examined in both individual and dual fuel mode at a constant gas flow rate of $21.69 \mathrm{~kg} /$ hour at various loading conditions. Secondly, the same test fuels were taken at constant load and different gas flow rates at $10 \mathrm{KW}$ in dual mode. An engine test analysis was carried out at varying load conditions $(0 \mathrm{~kW}, 2 \mathrm{~kW}, 4 \mathrm{~kW}, 6 \mathrm{~kW}, 8 \mathrm{~kW}$, and $10 \mathrm{~kW})$ by keeping the producer gas flow rate constant i.e. at $21.69 \mathrm{~kg} / \mathrm{h}$. All emissions were seen to be on the higher side for preheated oil as compared to biodiesel producer gas dual fuel mode at all load conditions. The nitrogen oxides and smoke opacity were reduced, whereas carbon dioxide, carbon monoxide and hydrocarbon were increased for all test fuels in dual fuel operation as compared to a single style at different loading conditions. All fuel blends showed better emissions than that of diesel in both ways. Utilising jojoba biodiesel producer gas dual fuel mode, emission parameters like $\mathrm{CO} 2$, smoke and $\mathrm{NO}_{\mathrm{x}}$ are higher as compared to diesel producer gas operation. At optimal load condition, smoke emission for preheated oil producer gas dual fuel operation is $62 \%$ higher than the diesel producer gas mode. Diesel savings for diesel producer gas operation fetch up to $83 \%$ when correlated with B20 biodiesel producer gas blend up to $81.6 \%$, at optimal load condition. Hence, it might be concluded that jojoba biodiesel producer gas up to $20 \%$ blend, i.e. B20, can be utilised as potential fuel for presenting diesel engine without much engine modification. Nevertheless, in the second case, with an increase in gas flow rate, all blended fuels showed better emissions with respect to diesel. The current paper also recommends further investigation to improve fuel properties and in-cylinder combustion phenomena of jojoba biodiesel before its usage in a dual fuel operated diesel engine.
\end{abstract}

Keywords: biodiesel, producer gas, dual fuel, twin cylinder, emission

\section{INTRODUCTION}

India is one of the most populated rural areas, with the highest energy consumption of resources on Earth. It relies on others because of depletion of energy reserves. According to literature, India has abundant vegetable oil sources [1]. Diesel, having the highest brake thermal efficiency, is the most popular in agriculture and transport sectors as compared 
to petrol fuels. Thus a huge quantity of diesel fuel is consumed in the agricultural sector. Due to rapid diesel fuel depletion, its escalating prices and hazardous emissions from vehicles have gathered momentum to find an option that can substitute petrol fuels in present engines. Vegetable oils are abundantly available in India, but they possess some problems when subjected to extended use in compression ignition (C. I) engines, which are attributed to its high viscosity and low volatility. Biodiesel derived from various nonedible oils can be utilised as an alternative fuel for diesel engines because it does not involve any modification [2]. The Jojoba plant, which generally develops in waste terrains of India, has become worthy for its oil, which is a fluid wax ester separated from the seed. Likewise, the plant is utilised to combat and avert desertification in the Thar Desert of India. A Jojoba plant develops to 1-2 metres (3.3- $6.6 \mathrm{ft}$ ) tall, with a wide, thick crown. Yet, there are reports of Jojoba plants as tall as 3 metres $(9.8 \mathrm{ft})$ [3]. The leaves are inversed, oval fit as a fiddle, 2-4 centimetres in length and 1.5-3 centimetres broad thick waxy glaucous light black green in shade. The blossoms are little, greenish-yellow, with 5-6 petals but no sepals. The yield of Jojoba seeds is about $0.8 \mathrm{~kg} / \mathrm{m}^{2}$ per annum and the petroleum content in it ranges is from $54 \%$ by weight. The main issue of kernel per tree is around 9-90 kilo per year [4] and the oil production potential is 1, 38, 000 million tonne. Free fatty acids composition of Jojoba oil is shown in Table 1 [5]. Biodiesel is chemically obtained from vegetable oil by a transesterification process.

Table 1. Free fatty acid composition of jojoba oil [5].

\begin{tabular}{|c|c|c|c|c|}
\hline Fatty Acid & Structure & $\begin{array}{l}\text { Amount } \\
(\%)\end{array}$ & Chemical Structure & Systematic name \\
\hline Palmitic & 16:0 & 1.60 & $\mathrm{CH}_{3}\left(\mathrm{CH}_{2}\right)_{14} \mathrm{COOH}$ & Hexadecanoic \\
\hline Palmitoleic & $16: 1$ & 0.10 & $\mathrm{C}_{16} \mathrm{H}_{30} \mathrm{O}_{2}$ & $\begin{array}{l}\text { 9-cis- } \\
\text { Hexadecanoic } \\
\text { acid }\end{array}$ \\
\hline Stearic & 18:0 & 0.14 & $\mathrm{CH}_{3}\left(\mathrm{CH}_{2}\right)_{16} \mathrm{COOH}$ & Octadecanoic \\
\hline Oleic & 18:1 & 11.20 & $\mathrm{CH}_{3}\left(\mathrm{CH}_{2}\right)_{7} \mathrm{CH}=\mathrm{CH}\left(\mathrm{CH}_{2}\right)_{7} \mathrm{COOH}$ & $\begin{array}{l}\text { Cis-9- } \\
\text { Octadecanoic }\end{array}$ \\
\hline Eicosanoic & 20:0 & 0.20 & $\mathrm{CH}=\mathrm{CHCH}_{2}=\mathrm{CH}\left(\mathrm{CH}_{2}\right)_{7} \mathrm{COOH}$ & - \\
\hline Eicosenoic & 20:1 & 70.70 & $\mathrm{C}_{20} \mathrm{H}_{60} \mathrm{O}_{2} \mathrm{CH}_{2}-\left(\mathrm{CH}_{2}\right)_{18} \mathrm{COOH}$ & - \\
\hline Docosanoic & 22:0 & 0.3 & $\mathrm{C}_{22} \mathrm{H}_{44} \mathrm{O}_{2}$ & - \\
\hline Erucic & 22:1 & 14.10 & $\mathrm{C}_{22} \mathrm{H}_{42} \mathrm{O}_{2}$ & $\begin{array}{l}\text { Cis-13- } \\
\text { docosanoic acid }\end{array}$ \\
\hline Tetracosanoic & 24:0 & 0.02 & $\mathrm{C}_{24} \mathrm{H}_{48} \mathrm{O}_{2}$ & - \\
\hline Nervonic & 24:1 & 1.64 & $\mathrm{C}_{24} \mathrm{H}_{46} \mathrm{O}_{2}$ & $\begin{array}{l}\text { Cis-15- } \\
\text { tetracosanoic acid }\end{array}$ \\
\hline
\end{tabular}

According to [6-8], a diesel engine operated in dual fuel mode gives improved emissions as compared to that of a normal running mode with enhanced brake thermal efficiency. A diesel engine can be modified to operate in dual fuel mode by inducting a producer gas; i.e., gaseous fuel as primary fuel followed by ignition with biodiesel or diesel as pilot fuel. The producer gas can be generated from various biomass feedstock samples by converting them into gaseous fuel with the help of a gasifier [9]. Producer gas cannot be used in diesel engines with a lower quantity of fuel due to its high octane number $[10,11]$. Hence, the engine needs to be dual fuelled. From the literature, it is visible that $76-93 \%$ diesel savings occur in the case of running the engine in a dual fuel mode by using various alternative fuels $[9,12,13]$. Biomass-derived producer gas can 
be used as an alternative fuel for diesel engine due to their eco-friendly nature $[14,15]$.

Table 2. Properties of the Producer Gas from Coir Pith [16].

\begin{tabular}{lc}
\hline Characteristics & Corresponding Values \\
\hline Bulk Density $\left(\mathrm{Kg} / \mathrm{m}^{3}\right)$ & 47 \\
Moisture content $(\% \mathrm{wb})$ & 10.6 \\
Volatile matter $(\% \mathrm{db})$ & 83.99 \\
Calorific value $\left(\mathrm{Kg} / \mathrm{m}^{3}\right)$ & 4182 \\
Octane number & $101-109$ \\
Laminar burning velocity & $0.6 \pm 0.06 \mathrm{~m} / \mathrm{s}$ \\
\hline
\end{tabular}

Table 3. Composition of the Producer Gas from Coir Pith [16].

\begin{tabular}{lc}
\hline Composition details Corresponding Values \\
\hline Carbon monoxide & $18 \pm 4 \%$ \\
Carbon dioxide & $11 \pm 2 \%$ \\
Hydrogen & $19 \pm 2 \%$ \\
Nitrogen & $49 \%$ \\
Methane & Up to $4.2 \%$ \\
Water vapour & $3 \%$ \\
Hydrocarbons & $0.3 \%$ \\
\hline
\end{tabular}

Producer gas on burning emits fewer oxides of nitrogen and smoke, which are the main cause of acid rain and smog formation [17]. Producer gas cannot be run in a diesel engine with less fuel quantity being injected because of its high octane number. Thus, diesel engine needs to be dual fuelled. Power derating is one of the major problems with producer gas when operated in a gasoline engine [18-20]. From the derating point of view and fuel flexibility, dual fuel engine is widely used for centralised power generation and agricultural purposes [21]. Modification of diesel engine into a dual fuel mode for producer gas is quite simple and power duration is restricted to about 25-35 $\%$. From the literature survey, it was revealed that $76-93 \%$ diesel may be saved in dual fuel mode by using an alternative fuel [21-23]. Dissimilar cases of dual fuel generally used are hydrogen, compressed natural gas (CNG), liquid petroleum gas (LPG), alcohol and so on [22, 24-26]. Now a day dual fuel engine can be interchangeably operated, i.e., either by using gaseous fuel and diesel fuel or completely using pilot fuel in the engine. Due to this switchover mechanism from dual mode to single-mode operation, it retains most of its features same as that of diesel engines [27, 28]. The principle of applying dual fuel engine is to reduce $\mathrm{NO}_{\mathrm{x}}$ and smoke emissions. In case of diesel engine, it is difficult to reduce both $\mathrm{NO}_{\mathrm{x}}$ and smoke emissions because of the tradeoff curve between them [16]. The most appropriate technique to solve this problem is by using alternative oxygenated fuel which provides more oxygen for burning. Gasification is the process for solid and liquid biofuel conversion into gaseous fuels in a gasifier in the pyrolysis process at high temperature. Producer gas having low calorific value is generated by the rebirth of high calorific value coir in a gasifier. It is a mix of carbon monoxide, hydrogen, carbon dioxide, methane, and nitrogen. Distinctive properties and composition of producer gas obtained from coir pith is shown in Table 2 and 3 [29]. From the literature review, it is discovered that coir pith producer gas in a single cylinder diesel locomotive can move efficiently up to $50-60 \%$ of full freight and then decreases [30]. Many researchers during their research study have mentioned that maximum diesel 
saving may occur up to $63-66 \%$ [30] , 72-75\% [29] , 72-74\% [31] by using producer gas from coir at optimum load conditions. The main objective of current work is to test the technical feasibility of using jojoba oil under preheated condition, and its methyl ester, in combination with coir pith producer gas in dual fuel mode in a diesel engine as a substitute for diesel fuel. The current paper also recommends further investigations to improve fuel properties and in-cylinder combustion phenomena of jojoba biodiesel before its usage in a dual fuel operated diesel engine.

\section{MATERIAL AND METHODS}

\section{Jojoba oil for diesel locomotives}

The Jojoba plant to a great extent develops in waste terrains of India has become worthy of its oil; i.e., a fluid wax ester separated from the seed. The plant has likewise been utilised to combat and avert desertification in the Thar Desert in India. Jojoba plants develop to 1-2 metres (3.3- $6.6 \mathrm{ft}$ ) tall, with a wide, thick crown. Yet there were reports of plants as tall as 3 metres $(9.8 \mathrm{ft})$ The leaves are inversed, oval fit as a fiddle, 2-4 centimetres in length and 1.5-3 centimetres broad, thick waxy glaucous ash green in shade. The blossoms are little, greenish- yellow, with 5-6 petals and with no sepals. The yield of Jojoba seeds is around $0.8 \mathrm{~kg} / \mathrm{m}^{2}$ for every annum and the petroleum content in it goes from $54 \%$ by weight to $67 \%$ by weight. The high oil content, easy availability, growth on barren lands, and low water requirement are the properties which make this oil best suitable for the investigation of diesel engine without much modification.

\section{Preparation of biodiesel}

The raw Jojoba oil collected from the mill undergoes degumming process where phosphorus is removed by using $1 \% \mathrm{v} / \mathrm{v}$ phosphoric acid. Degumming process is then accompanied by acid treatment, where Jojoba oil is mixed with $20 \% \mathrm{v} / \mathrm{v}$ of methanol and $1 \% \mathrm{v} / \mathrm{v}$ of sulfuric acid and followed by stirring for at least two hours at or below a temperature of $55{ }^{\circ} \mathrm{C}$, above which methanol will evaporate. It was then taken root for approximately 10-14 hours to separate glycerol and acid treated oil. The petroleum is now combined with a reagent mixture obtained from $20 \% \mathrm{v} / \mathrm{v}$ methanol and base catalyst potassium hydroxide $(\mathrm{KOH})(0.5 \% \mathrm{v} / \mathrm{v})$. The mix was then continuously stirred for $2-3$ hours below $60{ }^{\circ} \mathrm{C}$ and followed by a settling process to separate glycerol and base catalysed oil (Jojoba oil methyl ester). Water wash process was taken out with the base catalysed oil to help with distilled water and 1-3 drops of $\mathrm{KOH}$ for 5-6 times to separate oil and urine. The obtained oil was then heated to around $110{ }^{\circ} \mathrm{C}$ to remove any methanol or water particle present to obtain pure Jojoba biodiesel.

\section{Preparation of different blends of biodiesel and neat oil}

The Jojoba biodiesel and pure Jojoba oil blend with diesel fuel in various proportions; i.e., B10, B20, B30, J10, and $\mathrm{J} 20$. The B10 blend is prepared by mixing $10 \%$ of biodiesel with $90 \%$ of diesel. Similarly, J10 blend is made by mixing $10 \%$ of preheated Jojoba oil with $90 \%$ diesel by weight.

\section{Determination of fuel properties}

Before the application of the prepared biodiesel blend and pure oil in diesel engine, they are to be tested for determining some of their properties, like flash and fire point, viscosity, carbon residue, free fatty acid, cetane number, calorific value, pour point and cloud point by using various ASTM methods [32]. The properties are being presented in 
Table 4. The kinematic viscosity is an estimation of an oil density after a certain period of time. The lesser the density, the easier is its flow. In the case of an engine, an increased viscosity prompts improper working of the fuel injector thereby leading to a poor atomisation of the fuel spay, which develops an average mean distance across the fuel beads. ASTM D445 is the favoured system for measuring the kinematic viscosity. The adequate range for the oil density, according to ASTM D6751, is within $1.9-6.0$ $\mathrm{mm} 2 / \mathrm{Sec}$ [33]. Similarly, with respect to transportation and security regulations, a flash point is generally used to represent the ignition properties of a biodiesel. The flash point is the lowest temperature at which the fuel will ignite when an ignition source is connected. Biodiesel is considered non-flammable if the flash point is over the limit of $130{ }^{\circ} \mathrm{C}$, as outlined in ASTM D93.

Table 4. Properties of Preheated Jojoba oil and Jojoba oil methyl ester (JOME).

\begin{tabular}{lccc}
\hline \multicolumn{1}{c}{ Properties } & Diesel & Jojoba oil & JOME \\
\hline Density $\left(\mathrm{kg} / \mathrm{m}^{3}\right)$ & 846.3 & 887.3 & 864 \\
Kinematic Viscosity at $40{ }^{0} \mathrm{C}$ & 3.64 & 45.7 & 4.28 \\
Acid Value $(\mathrm{mg} \mathrm{KOH} / \mathrm{gm})$ & 0.35 & 0.68 & 0.02 \\
FFA $(\mathrm{mg}$ of $\mathrm{KOH} / \mathrm{gm})$ & 0.175 & 5.2 & 0.395 \\
Cloud point ${ }^{0} \mathrm{C}$ & -14 & 8 & -10 \\
Pour point ${ }^{0} \mathrm{C}$ & -15 & 5 & -16 \\
Flash point ${ }^{0} \mathrm{C}$ & 55 & 244 & 158 \\
Fire point ${ }^{0} \mathrm{C}$ & 74 & 283 & 179 \\
Calorific value $(\mathrm{MJ} / \mathrm{Kg})$ & 42.72 & 32.43 & 40.2 \\
Cetane Index & 48.3 & 42 & 46 \\
Carbon $(\%, \mathrm{w} / \mathrm{w})$ & 81.33 & 73.21 & 0.34 \\
Hydrogen $(\%, \mathrm{w} / \mathrm{w})$ & 12.78 & 9.92 & 12.19 \\
Nitrogen $(\%, \mathrm{w} / \mathrm{w})$ & 1.97 & $\mathrm{Nil}$ & $\mathrm{Nil}$ \\
Oxygen $(\%, \mathrm{w} / \mathrm{w})$ & 1.21 & 10.08 & 10.86 \\
Sulphur $(\%, \mathrm{w} / \mathrm{w})$ & 0.32 & Nil & $\mathrm{Nil}$ \\
Cold filter plugging point $\left({ }^{\circ} \mathrm{C}\right)$ & -25 to 0 & 20 & -16 \\
\hline
\end{tabular}

${ }^{\text {(d) }}$ Due to the wax ester nature of Jojoba oil, Iodine value was not calculated.

\section{Test Process and Methodology}

Figure 1 consists of a multi-cylinder, four-stroke vertical water cooled DI diesel engine, a downdraft gasifier with a gas flow rate of $30 \mathrm{~N}-\mathrm{M}^{3}$ hour, a gas cooler and filter. The detailed specification of the dual fuel engine and the downdraft gasifier are stated in Table 5 and 6 . Combustion of coir pith inside the gasifier reactor is converted into producer gas and then went through the cooler. Gas containing various unwanted materials is removed by passing through gas filter. A mechanical valve is applied at the filter vent to operate the gas flow rate. Orifice meter is applied to measure gas flow and a manometer to measure air and gas separately. Mixing of both producer gas and air takes place in the mixing chamber from where it enters into the engine cylinder. The velocity of the engine remains constant, i.e., 1500 RPM has an injection pressure of 220 bars. The AVL 444 multi-gas analyser and AVL 437 smoke metre are utilised to measure the emission attributes and later one for smoke discharge. The range, resolution, and exactness of the aforementioned smoke metre and multi-gas analyser are demonstrated in Table 7 and 8. Different tests were taken to evaluate the engine operation and emission parameters. Two different methods were preferred to bear out the operations. Firstly, the 
test was done by using diesel, and different biodiesel blends like B10, B20, and B30 on single-mode and then blending the same fuel blends with producer gas with a constant gas flow rate of $21.69 \mathrm{~kg} /$ hour in a dual mode for different loads, i.e. $0,2,4,6,8$, and 10 $\mathrm{kW}$. The same examination is again repeated for diesel, J10, and J20 blends and their mixing with producer gas with constant gas flow rates in dual fuel mode at different loading conditions. Secondly, the test is conducted with the same test fuels under different gas flow rates, i.e. $0,11.85,16.72,19.72$, and $21.69 \mathrm{~kg} /$ hour at a constant load of $10 \mathrm{~kW}$. Likewise, the same experiment is conducted by using test fuels like diesel, $\mathrm{J} 10$ and $\mathrm{J} 20$, for different gas flow rates at a constant load of $10 \mathrm{~kW}$.

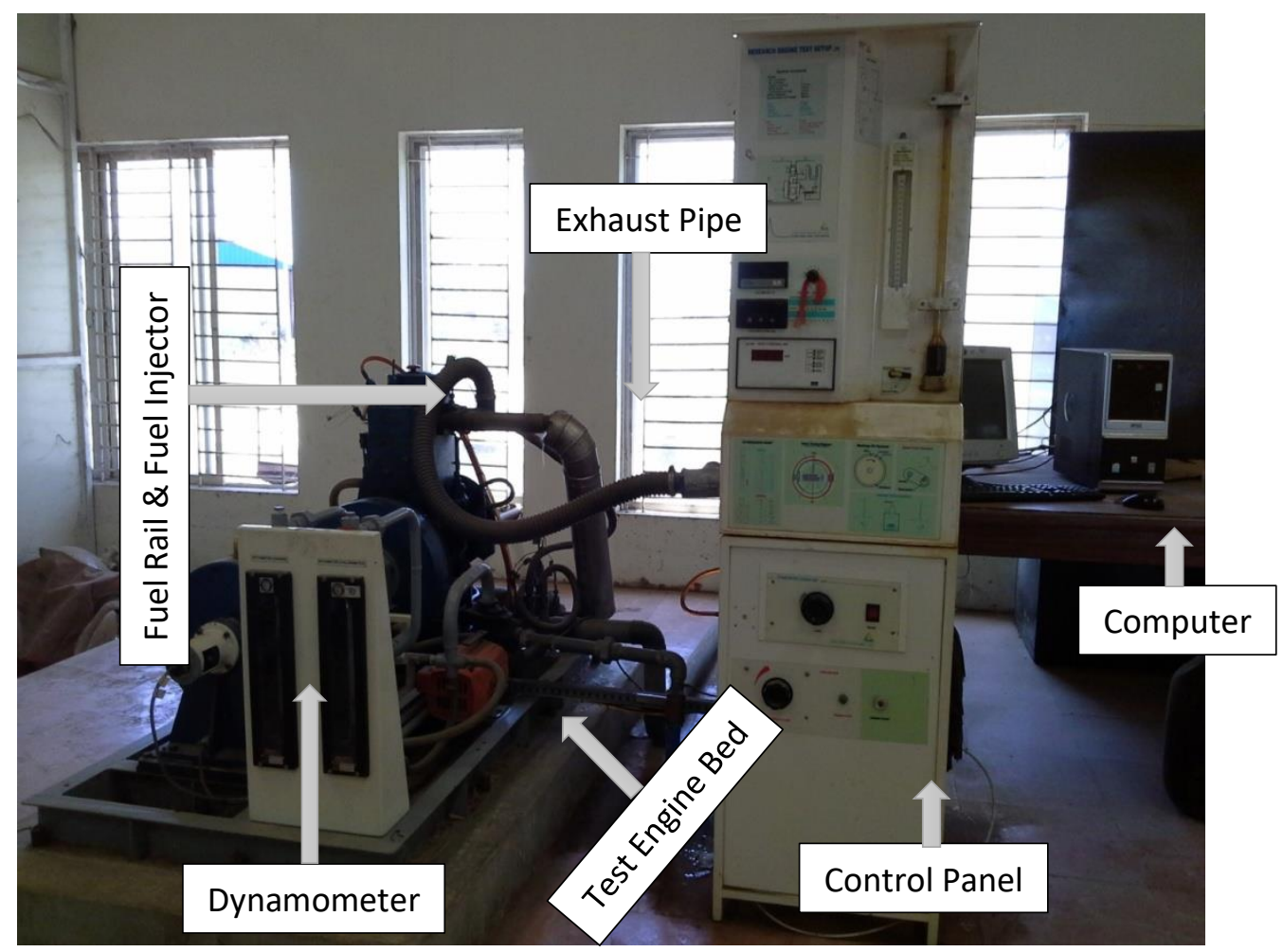

Figure 1. Test Engine setup.

Table 5. Specification of test engine and downdraft gasifier.

\begin{tabular}{lc}
\hline Make & $\begin{array}{c}\text { Four stroke vertical water cooled DI } \\
\text { diesel engine }\end{array}$ \\
Rated horse power $(\mathrm{HP})$ & 14 \\
No. of cylinders & 2 \\
No. of strokes & 4 \\
Rotation per minute $(\mathrm{rpm})$ & 1500 \\
Compression ratio & $16: 1$ \\
Stroke length $(\mathrm{mm})$ & 110 \\
Bore diameter $(\mathrm{mm})$ & 114 \\
\hline
\end{tabular}


Table 6. Specification of test engine and downdraft gasifier.

\begin{tabular}{ll}
\hline Model & WBG-10 clean gas model \\
Gasifier type & Down draft type \\
Gas flow rate & $30 \mathrm{NM}^{3} /$ hour \\
Average gas calorific value & $1000 \mathrm{Kcal} / \mathrm{Nm}^{3}$ \\
Gasification temperature & $1000{ }^{0} \mathrm{C}-1200^{0} \mathrm{C}$ \\
Fuel storage capacity & $100 \mathrm{Kg}($ approx.) \\
Permissible moisture & Less than $22 \%$ on a weight basis. \\
Rated hourly consumption & $7-10 \mathrm{Kg}$ \\
Ash drawer for ash removal & Manual \\
\hline
\end{tabular}

Table 7. Specification of AVL 437 smoke meter.

\begin{tabular}{llll}
\hline Parameters & Measuring range & Resolution & Accuracy \\
\hline Smoke Opacity & $0-100 \%$ & $0.1 \%$ & $\pm 1 \%$ \\
\hline
\end{tabular}

Table 8. Specification of AVL 444 multi-gas analyser.

\begin{tabular}{|c|c|c|c|}
\hline Parameters & Measuring range & Resolution & Accuracy \\
\hline $\mathrm{CO}$ & 0-10 \%vol. & $0.01 \%$ vol. & $\begin{array}{l}<0.6 \% \text { vol. } \pm 0.03 \% \text { vol. } \\
\geq 0.6 \% \text { vol. } \pm 5 \% \text { vol. }\end{array}$ \\
\hline $\mathrm{HC}$ & $\begin{array}{l}0-20000(\mathrm{ppm}) \\
\text { vol. }\end{array}$ & $\begin{array}{l}\leq 2000: 1(\mathrm{ppm}) \\
\text { vol. } \\
>2000: 10(\mathrm{ppm}) \\
\text { vol. }\end{array}$ & $\begin{array}{l}<200(\mathrm{ppm}) \text { vol. } \pm 10(\mathrm{ppm}) \\
\text { vol. } \\
\geq 200(\mathrm{ppm}) \text { vol. } \pm 5 \% \text { vol } .\end{array}$ \\
\hline $\mathrm{CO}_{2}$ & $0-20 \%$ vol. & $0.1 \%$ vol. & $\begin{array}{l}<10 \% \text { vol. } \pm 0.5 \text { vol. } \\
\geq 10 \% \text { vol. } \pm 5 \text { vol. }\end{array}$ \\
\hline NO & $0-22 \%$ vol. & $0.1 \%$ vol. & $\begin{array}{l}<2 \% \text { vol. } \pm 0.1 \% \text { vol. } \\
\geq 2 \% \text { vol. } \pm 5 \% \text { vol. }\end{array}$ \\
\hline $\mathrm{O}_{2}$ & 0-5000 (ppm) vol. & 1 (ppm) vol. & $\begin{array}{l}<500(\mathrm{ppm}) \text { vol. } \pm 50(\mathrm{ppm}) \\
\text { vol. } \\
\geq 500(\mathrm{ppm}) \text { vol. } \pm 10 \% \text { vol. }\end{array}$ \\
\hline
\end{tabular}

\section{RESULTS AND DISCUSSION}

\section{Carbon Monoxide}

From Figure 2(a-b), it may be concluded that $\mathrm{CO}$ emission is higher for dual fuel mode than that of single-mode for all test fuels under different loading conditions because of incomplete combustion and presence of $\mathrm{CO}$ in producer gas. With the increase in load, $\mathrm{CO}$ emission declines up to $8 \mathrm{~kW}$ because of the higher intake air temperature, which enhances the oxidation reaction. However, at peak load $\mathrm{CO}$ increases due to the fact that at peak load the amount of oxygen content in $\mathrm{A} / \mathrm{F}$ mixture reduces, thus resulting in partial or incomplete combustion [16]. CO emission decreases with increase in load because of perfect combustion and again, it increases in higher load because of fuel richness and incomplete burning [16]. With an increase in percentage of blends with diesel, CO emission decreases for both the operations because of the presence of oxygen in biodiesel [20]. In dual fuel mode $\mathrm{CO}$ emission is $84.4 \%$ higher than that of single mode for all test fuels at higher load. Figure 2(c-d) shows a linear increment in CO 
emission with respect to gas flow rate because of the presence of $\mathrm{CO}$ in the gas itself. Hence, the more flow rate of gas, the more will be the $\mathrm{CO}$ emission. The image brings out that petrodiesel shows highest CO emission of $0.68 \%$ and lowest for B20 of $0.53 \%$ amongst all test fuels at a higher gas flow rate because of better atomisation and lower carbon to hydrogen ratio.

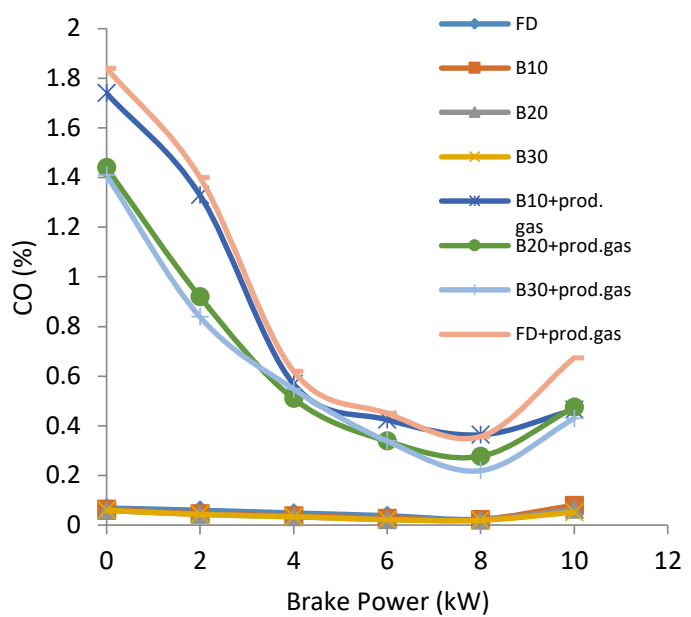

(a)

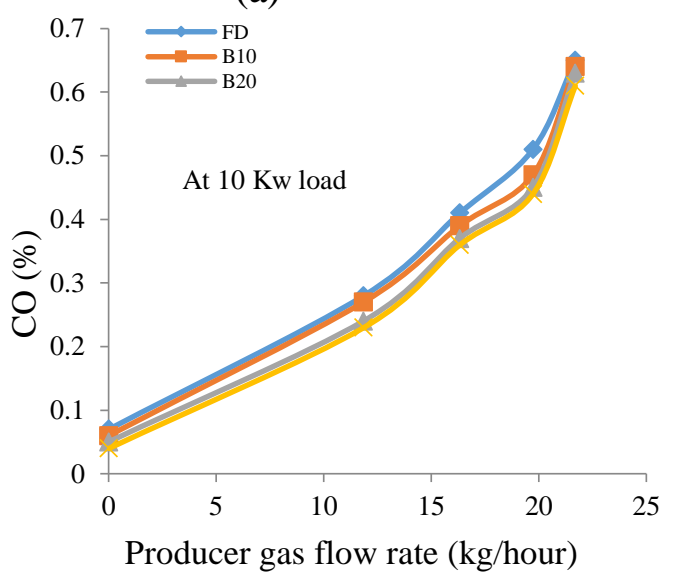

(c)

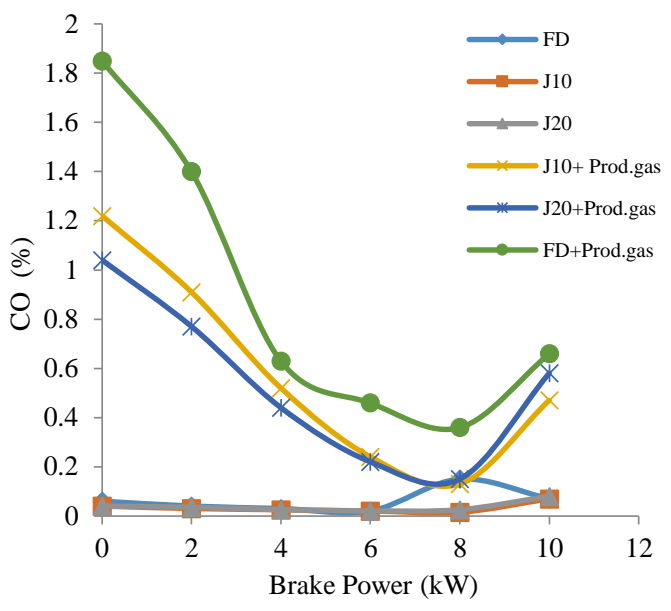

(b)

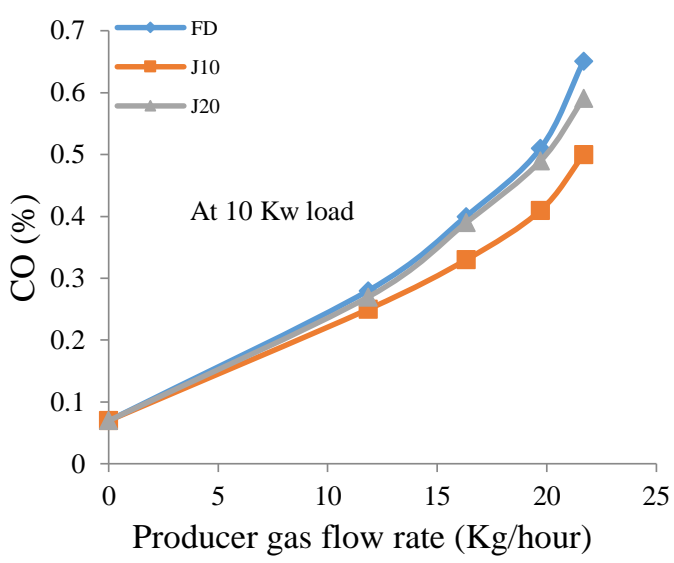

(d)

Figure 2. (a) Variations of $\mathrm{CO}$ with $\mathrm{BP}$, (b) Variations of $\mathrm{CO}$ with $\mathrm{BP}$, (c) Variations of $\mathrm{CO}$ with producer gas flow rate and (d) Variations of $\mathrm{CO}$ with producer gas flow rate.

\section{Hydrocarbon Emission}

From Figure 3(a-b), it may be concluded that $\mathrm{HC}$ emission shows very similar curves to that of $\mathrm{CO}$ emission. $\mathrm{HC}$ emission decreases for all fuel blends with diesel due to complete combustion of fuel blends. From the literature, it was stated that $\mathrm{HC}$ emission was less for blends of vegetable oil than that of diesel [4]. HC emission is $37.56 \%$, approximately more in dual fuel mode as compared to that of a single style because of incomplete combustion at higher load. Pattern 3(c) and Pattern 3(d) show that HC emission increases linearly with gas flow rate because of incomplete combustion or the slow-burning nature of the gaseous state. Increasing the percentage of blend with diesel leads to a decrease in $\mathrm{HC}$ emission due to a complete combustion because of the high cetane number and oxygen content in the biodiesel [16, 20, 29, 34]. From the flesh it was noted that $\mathrm{HC}$ emission at a higher gas flow rate for diesel showed a value of 65 ppm, whereas B30 give 44 ppm. 


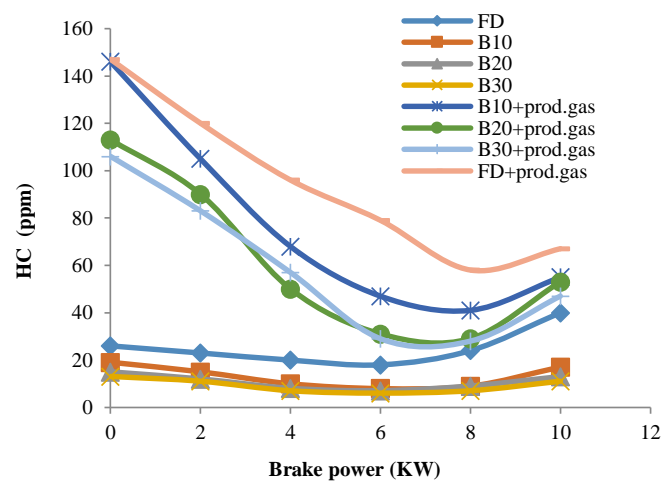

(a)

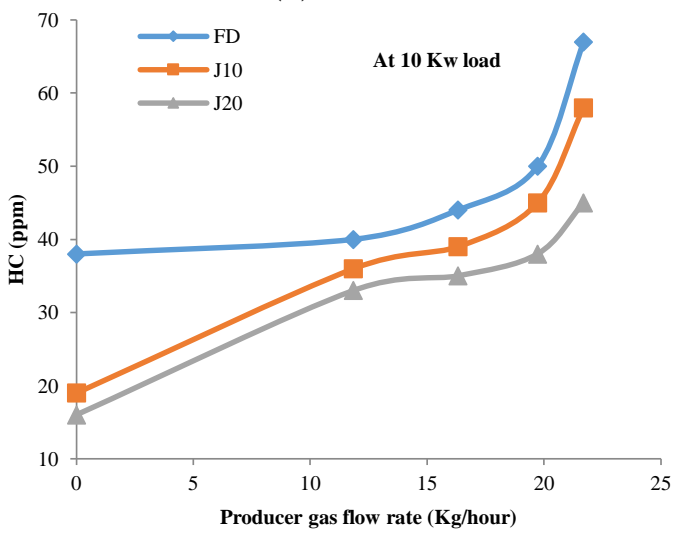

(c)

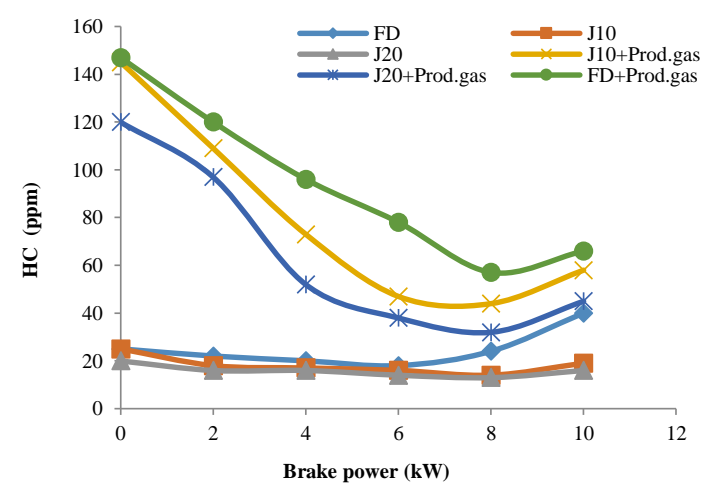

(b)

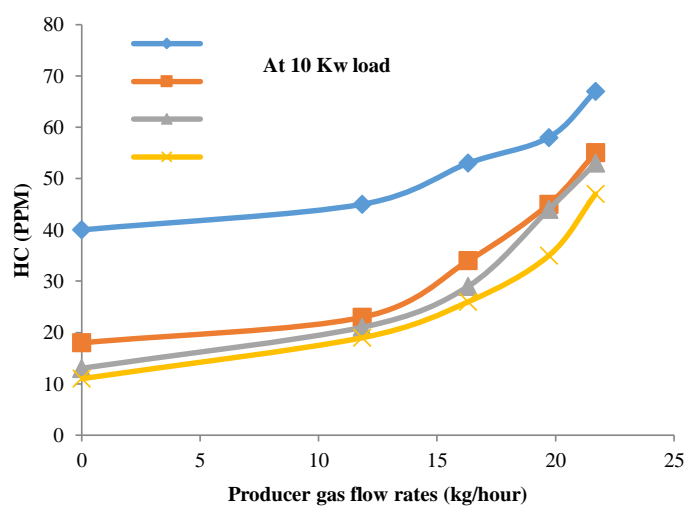

(d)

Figure 3. (a) Variations of HC with BP, (b) Variations of HC with BP, (c) Variations of $\mathrm{HC}$ with producer gas flow rate and (d) Variations of $\mathrm{HC}$ with producer gas flow rate.

\section{Carbon Dioxide}

From the above Figure 4(a-b), it may be concluded that $\mathrm{CO}_{2}$ emission in the first case is more for dual mode than that of single-mode operation for all the test fuels under different loading conditions. This is imputable to the fact that producer gas is a mixture of both $\mathrm{CO}$ and $\mathrm{CO}_{2}$, so when there is a complete combustion, there is an automatic increase in $\mathrm{CO}_{2}$ emission [31]. Biodiesel is an oxygenated fuel which burns clean and gives out less $\mathrm{CO}_{2}$ [24]. $\mathrm{CO}_{2}$ emission increases linearly with respect to cargo for both operational modes because of perfect combustion. The $\mathrm{CO}_{2}$ emission at higher load is $33.7 \%$ higher for dual fuel mode than that of the single operational mode. From Figure $4(\mathrm{c}-\mathrm{d})$, it may be concluded that $\mathrm{CO}_{2}$ emission increases with a gain in gas flow rate because of complete combustion [31]. Increasing the blending percentage for both biodiesel and preheated oil, $\mathrm{CO}_{2}$ emission reduce because both biodiesel and non-edible vegetable oil for burning emits less $\mathrm{CO}_{2}$ [24]. From the graph, it was noted that $\mathrm{CO}_{2}$ emission at a higher gas flow rate for diesel showed a value of $6.42 \%$ and that of B30 was $5.34 \%$.

\section{Oxides of Nitrogen}

From Figure 5(a-b), it may be concluded that $\mathrm{NO}_{\mathrm{x}}$ emission is lower for dual fuel mode than that of single mode because of the absence of nitrogen in producer gas and has low adiabatic flame temperature [4]. Referable to the gain in energy input, $\mathrm{NO}_{\mathrm{x}}$ emission increases with regards to cargo for both operation instances. Again, with an increase in blend per cent, $\mathrm{NO}_{\mathrm{x}}$ emission reduce because of low peak combustion 
temperature as less amount of energy was liberated during a combustion period [35]. From Figure 5(c-d), $\mathrm{NO}_{\mathrm{x}}$ emission decrease with an increase in flow rate of gas because of the low adiabatic flame temperature and absence of nitrogen in the gas [4]. $\mathrm{NO}_{\mathrm{x}}$ emission at a higher gas flow rate for diesel showed a value of $173 \mathrm{ppm}$ and J20 gives the lowest of $55 \mathrm{ppm}$ as compared to other test fuels.

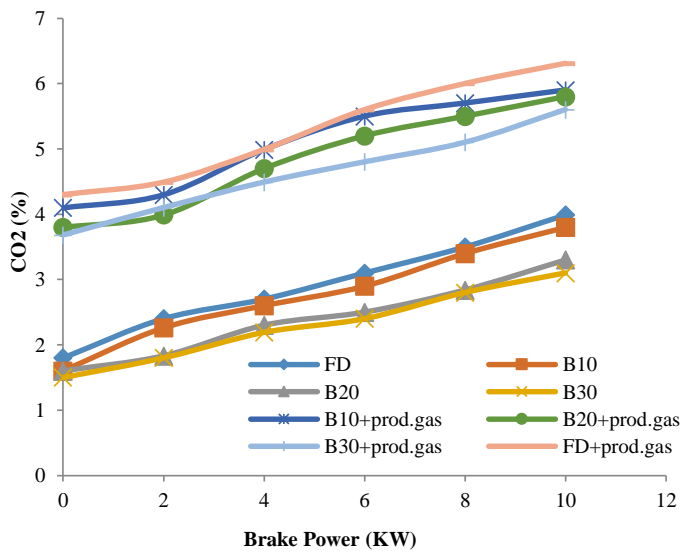

(a)

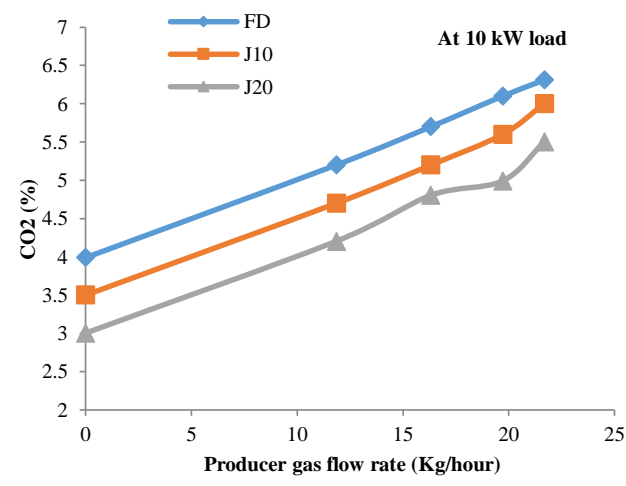

(c)

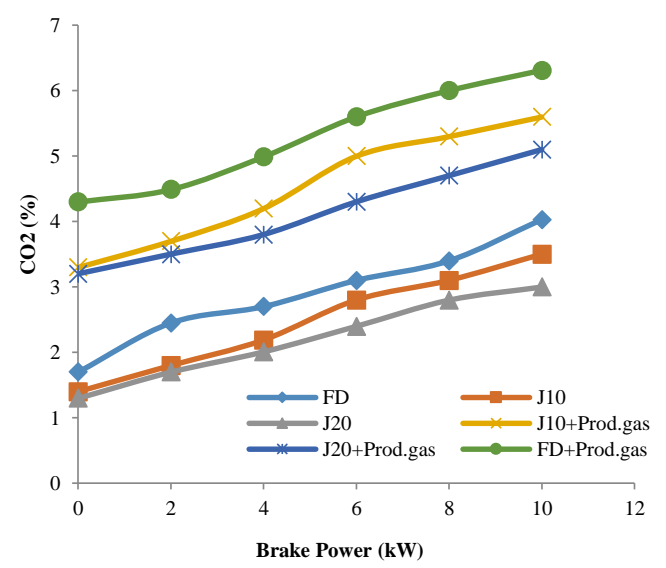

(b)

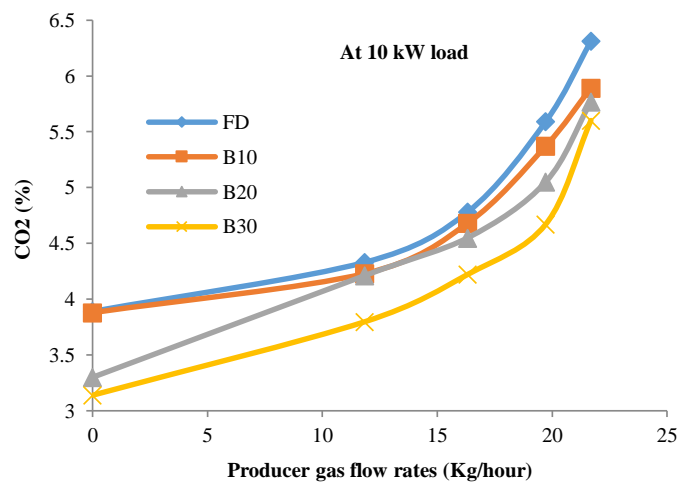

(d)

Figure 4 (a) Variations of $\mathrm{CO}_{2}$ with $\mathrm{BP}$, (b) Variations of $\mathrm{CO}_{2}$ with $\mathrm{BP}$, (c) Variations of $\mathrm{CO}_{2}$ with producer gas flow rate and (d) Variations of $\mathrm{CO}_{2}$ with producer gas flow rate

\section{Smoke Opacity}

From the above Figure 6(a-b), it may be concluded that smoke opacity in dual fuel mode is less as compared to that of single-mode operation because of the clean burning of the producer gas and reduction in diesel fuel injection in dual fuel at high load. Smoke opacity increases with the growth in shipment for both styles because of incomplete combustion or insufficient air supply with an increase in payload. Again, with an increase of diesel blend proportion smoke opacity reduces due to better combustion because of its high cetane number and presence of oxygen in biodiesel [9, 12, 35]. From Figure 6(c-d), it may be revealed that with the growth in gas flow rate smoke opacity decreases because of the clean producer gas burning. B20 blend showed the lowest value of smoke opacity of around $31-35 \%$, while diesel showed the highest value of close to $65-68 \%$ among all test fuels. 


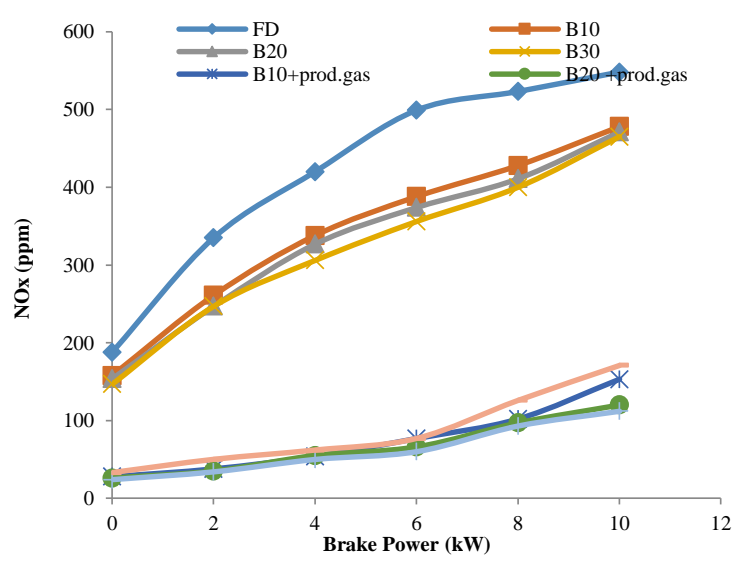

(a)

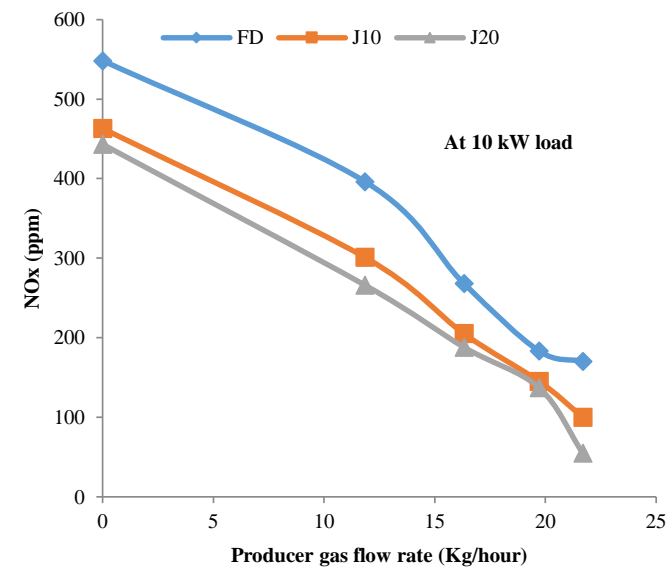

(c)

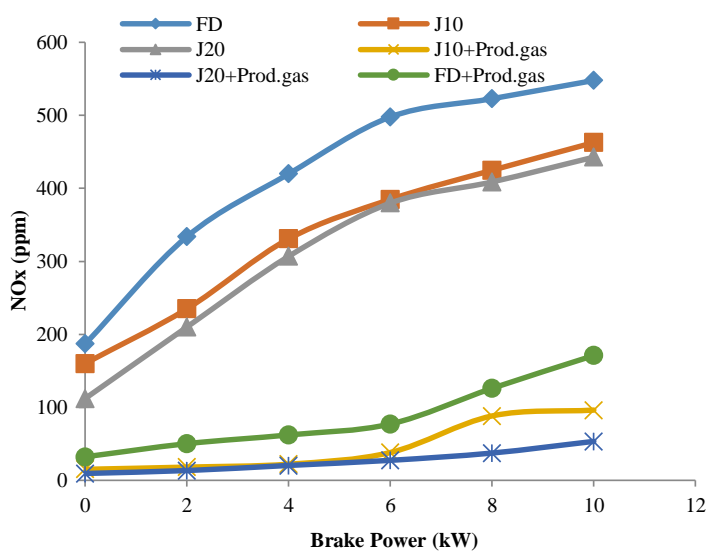

(b)

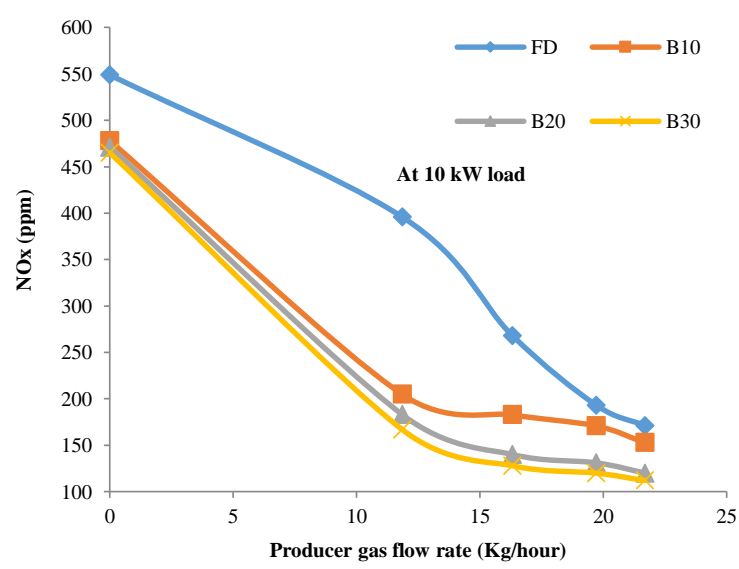

(d)

Figure 5 (a) Variations of $\mathrm{NO}_{\mathrm{x}}$ with $\mathrm{BP}$, (b) Variations of $\mathrm{NO}_{\mathrm{x}}$ with $\mathrm{BP}$, (c) Variations of $\mathrm{NO}_{\mathrm{x}}$ with producer gas flow rate and (d) Variations of $\mathrm{NO}_{\mathrm{x}}$ with producer gas flow rate

\section{Pilot Fuel Savings}

The variation of pilot fuel savings with respect to load in terms of per cent is shown in Figure 7(a) in dual fuel mode of operation. It is observed that the highest amount of diesel saved are $79 \%, 78 \%, 76 \%$, and $82 \%$ in the case of B10, B20, B30, and Fossil Diesel at $8 \mathrm{~kW}$ of load. It is also determined from the pattern that with the increase in the blending per cent of biodiesel pilot fuel savings decreased because of low calorific value of vegetable oils [12]. Similarly, again in Figure 7(b) the amount of pilot fuel savings increases with regards to an increase in gas flow rate which is due to large amount of energy being furnished by the gaseous fuels. The maximum quantity of fuel savings in later case is noted to be 54\%, 55\% and 58\% for fossil diesel, J10, and $\mathrm{J} 20$ at maximum producer gas flow rate. 


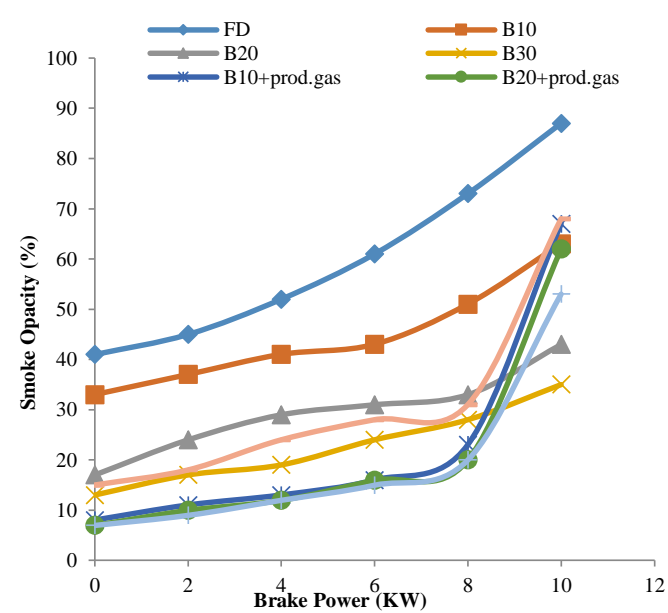

(a)

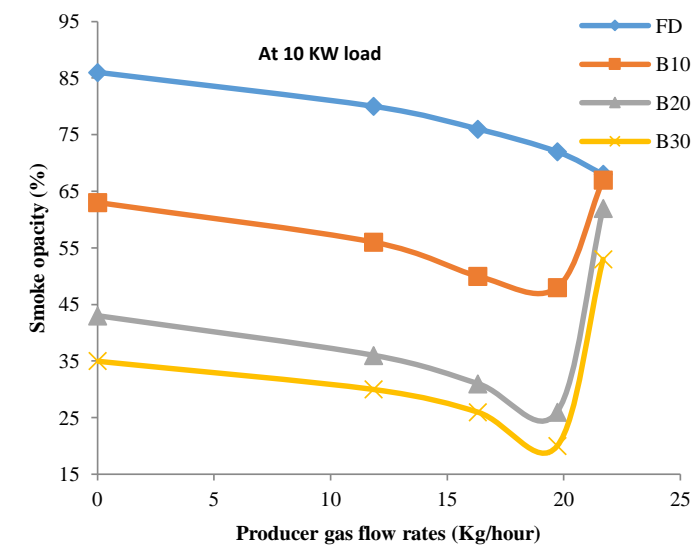

(c)

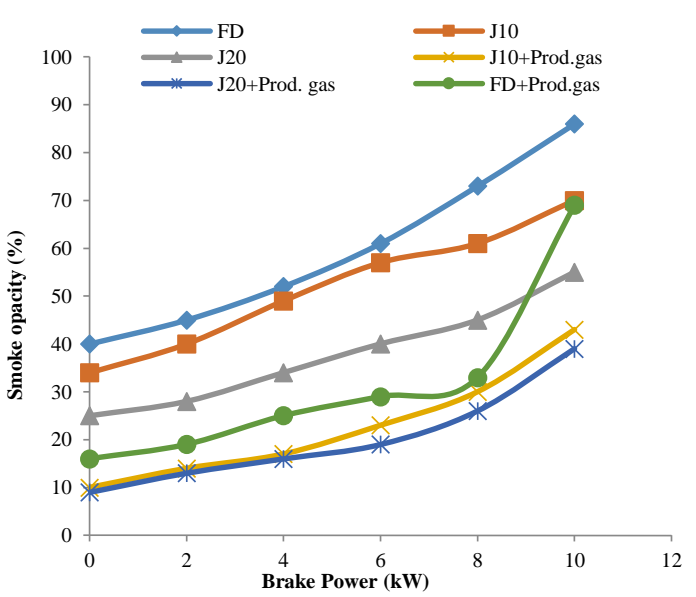

(b)

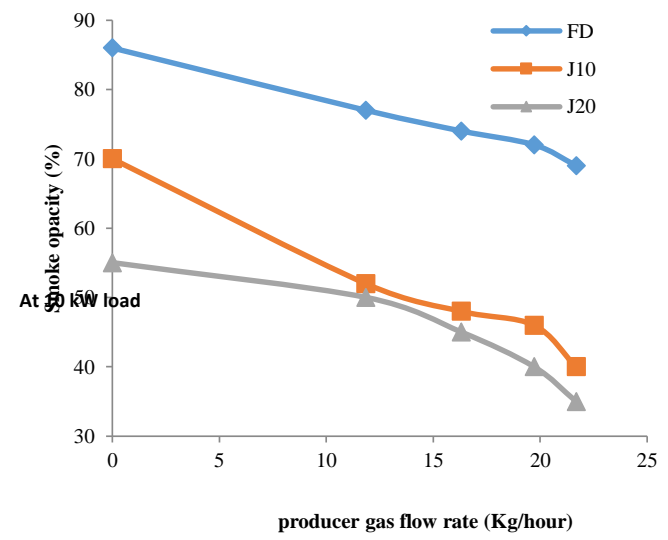

(d)

Figure 6 (a) Variations of smoke opacity with BP, (b) Variations of smoke opacity with BP, (c) Variations of smoke opacity with producer gas flow rate and (d) Variations of smoke opacity with producer gas flow rate.

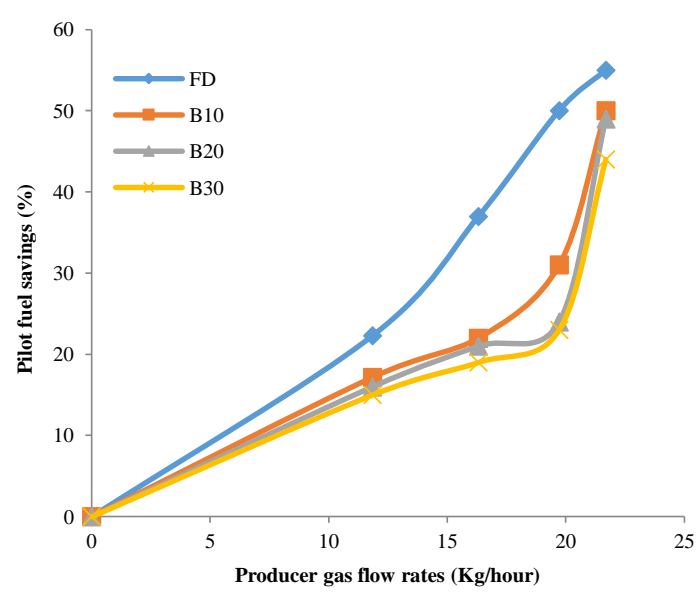

(a)

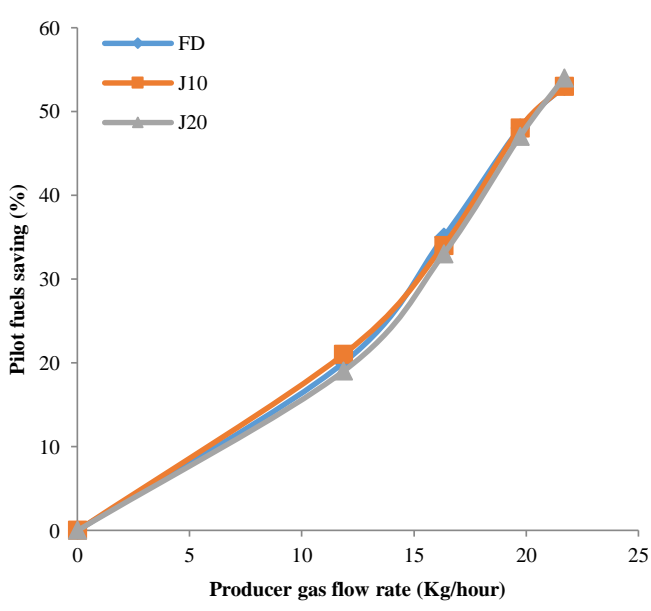

(b)

Figure 7(a) Variations of Pilot fuel savings with Producer gas flow rate and (b) Variation of Pilot fuel savings with Producer gas flow rate 


\section{CONCLUSIONS}

The primary objective of the present investigation was to test the effectiveness of preheated jojoba oil with producer gas and jojoba biodiesel with producer gas in dual fuel mode. The secondary objective was to measure the various engine emission parameters for the above said test fuels. The following conclusion were drawn from the experimentation:

i) Maximum diesel savings occurred for diesel with producer gas up to $82 \%$, when correlated with the B20 biodiesel blend showing a diesel savings rate of up to $80.6 \%$ at $8 \mathrm{~kW}$ of the optimum loading condition

ii) $\mathrm{NOx}$ and smoke opacity was reduced, whereas $\mathrm{CO}, \mathrm{CO}_{2}$ and $\mathrm{HC}$ were more in the case of dual fuel mode as compared to that of single-mode for all test fuels. It was also observed, that with an increase in gas flow rates, $\mathrm{NO}_{\mathrm{x}}$ and smoke opacity decreased while $\mathrm{CO}, \mathrm{CO}_{2}$ and $\mathrm{HC}$ increased in dual fuel operation.

Hence, from the above experimental analysis it is confirmed that jojoba biodiesel oil up to $20 \%$; i.e., J20, biodiesel B10 and producer gas from coir pith can be utilised as a substitute fuel which may be helpful in bringing down the hazardous emission coming out of the engine without modifications.

\section{ACKNOWLEDGEMENTS}

The authors are very much grateful and thankful to the School of Mechanical Engineering, KIIT University, for providing the experimental setup and space for carrying out the experimentation.

\section{REFERENCES}

[1] Hotti SR, Hebbal O. Performance and combustion characteristics of single cylinder diesel engine running on Karanja oil/Diesel fuel blends. Scientific Research. 2011;3:371-5.

[2] Bajpai S, Sahoo P, Das L. Feasibility of blending karanja vegetable oil in petrodiesel and utilization in a direct injection diesel engine. Fuel. 2009;88:705-11.

[3] Gentry HS. The natural history of jojoba (Simmondsia chinensis) and its cultural aspects. Economic botany. 1958;12:261-95.

[4] Agarwal AK, Rajamanoharan K. Experimental investigations of performance and emissions of Karanja oil and its blends in a single cylinder agricultural diesel engine. Applied Energy. 2009;86:106-12.

[5] Zaher FA, El Kinawy OS, El Haron DE. Solvent extraction of jojoba oil from prepressed jojoba meal. Grasas y aceites. 2004;55:129-34.

[6] Mohd Noor CW, Mamat R, Najafi G, Mat Yasin MH, Ihsan CK, Noor MM. Prediction of marine diesel engine performance by using artificial neural network model. Journal of Mechanical Engineering and Sciences. 2016;10:1917-30.

[7] Kettner M, Dechent S, Hofmann M, Huber E, Arruga H, Mamat R, et al. Investigating the influence of water injection on the emissions of a diesel engine. Journal of Mechanical Engineering and Sciences. 2016;10:1863-81.

[8] Ibrahim F, Wan Mahmood WMF, Abdullah S, Abu Mansor MR. Numerical investigation of soot mass concentration in compression ignition diesel engine. Journal of Mechanical Engineering and Sciences. 2016;10:2275-87. 
[9] Khalid A, Tajuddin ASA, Jaat N, Manshoor B, Zaman I, Hadi SAA, et al. Performance and emissions of diesel engine fuelled with preheated biodiesel fuel derived from crude palm, jatropha, and waste cooking oils. International Journal of Automotive and Mechanical Engineering. 2017;14:4273-84.

[10] Dasappa S, Sridhar H. Performance of a diesel engine in a dual fuel mode using producer gas for electricity power generation. International Journal of Sustainable Energy. 2013;32:153-68.

[11] Nayak SK, Mishra PC. Application of Nagchampa biodiesel and rice husk gas as fuel. Energy Sources, Part A: Recovery, Utilization, and Environmental Effects. 2016;38:2024-30.

[12] Nayak SK, Mishra PC. Emission from a dual fuel operated diesel engine fuelled with Calophyllum Inophyllum biodiesel and producer gas. International Journal of Automotive and Mechanical Engineering. 2017;14:3954-69.

[13] Nwafor O. Effect of choice of pilot fuel on the performance of natural gas in diesel engines. Renewable Energy. 2000;21:495-504.

[14] Nwafor O, Rice G, Ogbonna A. Effect of advanced injection timing on the performance of rapeseed oil in diesel engines. Renewable Energy. 2000;21:43344.

[15] Henham A, Makkar M. Combustion of simulated biogas in a dual-fuel diesel engine. Energy Conversion and Management. 1998;39:2001-9.

[16] Ramadhas A, Jayaraj S, Muraleedharan C. Dual fuel mode operation in diesel engines using renewable fuels: Rubber seed oil and coir-pith producer gas. Renewable Energy. 2008;33:2077-83.

[17] Kaupp A. Small scale gas producer-engine systems: Springer Science \& Business Media; 2013.

[18] Vyarawalla F, Parikh P, Dak H, Jain B. Utilisation of biomass for motive power generation—gasifier engine system. Biomass. 1984;5:227-42.

[19] Parikh P, Bhave A, Kapse D. Study of thermal and emission performance of small gasifier-dual-fuel engine systems. Biomass. 1989;19:75-97.

[20] Bhattacharya S, Pham H-L. A study on a multi-stage hybrid gasifier-engine system. Biomass and bioenergy. 2001;21:445-60.

[21] Uma R, Kandpal T, Kishore V. Emission characteristics of an electricity generation system in diesel alone and dual fuel modes. Biomass and bioenergy. 2004;27:195-203.

[22] Ramadhas A, Jayaraj S, Muraleedharan C. Power generation using coir-pith and wood derived producer gas in diesel engines. Fuel Processing Technology. 2006;87:849-53.

[23] Selim M, Radwan MS, Elfeky SM. Combustion of jojoba methyl ester in an indirect injection diesel engine. Renewable Energy. 2003;28:1401-20.

[24] Alam M, Goto S, Sugiyama K, Kajiwara M, Mori M, Konno M, et al. Performance and emissions of a DI diesel engine operated with LPG and ignition improving additives. SAE Technical Paper; 2001.

[25] Badr O, Karim G, Liu B. An examination of the flame spread limits in a dual fuel engine. Applied Thermal Engineering. 1999;19:1071-80.

[26] Hossain AK, Davies PA. Plant oils as fuels for compression ignition engines: A technical review and life-cycle analysis. Renewable Energy. 2010;35:1-13.

[27] Hasan MM, Rahman MM, Kadirgama K. A review on homogeneous charge compression ignition engine performance using biodiesel-diesel blend as a fuel. 
International Journal of Automotive and Mechanical Engineering. 2015;11:2199211.

[28] Panneerselvam N, Murugesan A, Vijayakumar C, Subramaniam D. Performance, emissions and combustion characteristics of $\mathrm{CI}$ engine fuel with watermelon (Citrullus vulgaris) methyl esters. International Journal of Ambient Energy. 2017;38:308-13.

[29] Ghosh S, Das TK, Jash T. Sustainability of decentralized woodfuel-based power plant: an experience in India. Energy. 2004;29:155-66.

[30] Banapurmath N, Tewari P, Yaliwal V, Kambalimath S, Basavarajappa Y. Combustion characteristics of a 4-stroke CI engine operated on Honge oil, Neem and Rice Bran oils when directly injected and dual fuelled with producer gas induction. Renewable Energy. 2009;34:1877-84.

[31] Senthil kumar M, Ramadhas A, Nagalingam B. Experimental investigation on Jojoba oil-methanol dual fuel engines. SAE Technical Paper. 2001;2001-010153:1-7.

[32] Atabani A, da Silva César A. Calophyllum inophyllum L.-A prospective nonedible biodiesel feedstock. Study of biodiesel production, properties, fatty acid composition, blending and engine performance. Renewable and Sustainable Energy Reviews. 2014;37:644-55.

[33] Nayak SK, Mishra PC. Emission from utilization of producer gas and mixes of jatropha biodiesel. Energy Sources, Part A: Recovery, Utilization, and Environmental Effects. 2016;38:1993-2000.

[34] Hasan MM, Rahman MM. Homogeneous charge compression ignition combustion: Advantages over compression ignition combustion, challenges and solutions. Renewable and Sustainable Energy Reviews. 2016;57:282-91.

[35] Sureshkumar K, Velraj R, Ganesan R. Performance and exhaust emission characteristics of a CI engine fueled with Pongamia pinnata methyl ester (PPME) and its blends with diesel. Renewable Energy. 2008;33:2294-302. 